\title{
Antioxidant and genotoxic properties of Maytenus dasyclada: a comparative study in relation to Maytenus reference species
}

\author{
Cansian, RL. ${ }^{a *}$, Kubiak, GB. ${ }^{a}$, Borsatti, L. ${ }^{a}$, Mielniczki-Pereira, AA. ${ }^{a}$, Roman, SS. ${ }^{a}$, \\ Paroul, N. ${ }^{a}$, Schwanz, M. ${ }^{b}$, Manfredini, $V^{c}$ and Mossi, AJ. ${ }^{d}$ \\ ${ }^{a}$ Universidade Regional Integrada do Alto Uruguai e das Missões - URI, Av. Sete de Setembro, 1621, \\ CEP 99700-000, Erechim, RS, Brazil \\ bUniversidade de Caxias do Sul - UCS, Rua Francisco Getúlio Vargas, 1130, CEP 95070-560, Caxias do Sul, RS, Brazil \\ 'Universidade Federal do Pampa - UNIPAMPA, BR 472, Km 592, CEP 97500-970, Uruguaiana, RS, Brazil \\ ${ }^{d}$ Universidade Federal da Fronteira Sul - UFFS,Av. Dom João Hoffmann, 313, CEP 99700-000, Erechim, RS, Brazil \\ *e-mail: cansian@uricer.edu.br
}

Received: October 10, 2013 - Accepted: December 4, 2013 - Distributed: May 31, 2015

(With 3 figures)

\begin{abstract}
In these work the in vitro antioxidant activity and the in vivo genotoxicity of $M$. dasyclada was compared to the reference species $M$. aquifolium and M. ilicifolia. M. dasyclada showed in vitro antioxidant activity comparable to

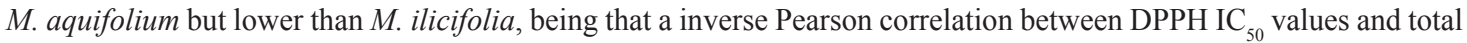
phenolic content was detected (-0.932). The carbonyl content of $M$. dasyclada and $M$. aquifolium extracts promoted a similar increase in protein oxidation in vivo, while $M$. ilicifolia no altered the carbonyl levels. The comet assay demonstrated that the three analyzed species promoted a low and similar level of genotoxicity; which is compatible with DNA damage induced by other medicinal plants and is partially recovered by a co-treatment with vitamin $\mathrm{C}$. The data showed M. dasyclada as antioxidant activity in vitro, and that its genotoxic and pro-oxidant effects in vivo are comparable to the Maytenus reference species.
\end{abstract}

Keywords: Maytenus ilicifolia, M. aquifolium, M. dasyclada, comet assay, antioxidant activity, phenolic pompounds.

\section{Propriedades antioxidantes e genotóxicas de Maytenus dasyclada: um estudo comparativo em relação às espécies de referência de Maytenus}

\section{Resumo}

No presente trabalho a atividade antioxidante in vitro e a genotoxicidade in vivo de $M$. dasyclada foi comparada com as espécies de referência M.aquifolium e M. ilicifolia. M. dasyclada mostrou atividade antioxidante in vitro comparável a de M. aquifolium mas inferior a M. ilicifolia, sendo que foi detectada uma correlação de Pearson inversa entre os valores de $\mathrm{IC}_{50}$ por DPPH e o conteúdo fenólico total $(-0,932)$. Em relação ao teor de carbonila, os extratos de $M$. dasyclada e M. aquifolium promoveram um aumento semelhante na oxidação das proteínas in vivo, ao passo que Maytenus ilicifolia não alterou os níveis de carbonila. O ensaio do cometa demonstrou que as três espécies analisadas promoveram um nível baixo e semelhante de genotoxicidade, o que é compatível com os danos no DNA induzidos por outras plantas medicinais e é parcialmente recuperada por um co-tratamento com a vitamina C. Os dados mostraram M. dasyclada com atividade antioxidante in vitro, e que os seus efeitos genotóxicos e pró-oxidantes in vivo são comparáveis às espécies de referência de Maytenus.

Palavras-chave: Maytenus ilicifolia, M. aquifolium, M. dasyclada, teste cometa, atividade antioxidante, substâncias fenólicas.

\section{Introduction}

Maytenus aquifolium Mart. (synonym M. aquifolia) and $M$. ilicifolia Mart. ex Reissek (synonym M. muelleri) (Celastraceae) are widely employed in Brazilian popular medicine, being known as 'espinheira-santa' or 'cancarosa'. Both are native plants, with natural occurrence in South of Brazil and are used in form of teas for stomach and ulcer illness treatment (Mariot and Barbieri, 2007). Souza-

Formigoni et al. (1991) have demonstrated the antiulcerogenic property of these two species, which seems to be closely related to the presence of two classes of substances, namely, phenols and triterpenes (Mossi et al., 2009).

This increasing interest by natural antioxidants is related to their low toxicity as compared to synthetic antioxidants (Soares et al., 2008). In these sense, investigations about 
the presence of new antioxidants in plants emerges as a natural alternative against the deleterious effects of reactive oxygen species (ROS) and free radicals (FR) (Galvão et al., 2008). Several works have already shown the antioxidant activity of $M$. aquifolium and $M$. ilicifolia (Corsino et al., 2003; Vellosa et al., 2007; Mariot and Barbieri, 2007; Pessuto et al., 2009), which probably is due to the action of polyphenols and flavonoids as the free radicals scavengers. The pharmacological properties of M. ilicifolia were reviewed in literature (Santos-Oliveira, 2009).

The production of ROS and FR can occur as consequence of exposition to toxic agents (radiation, antibiotics, several types of environmental pollutants, among others) or as result of normal metabolism in the living cells (Halliwell and Gutteridge, 2007). In situations where the ROS and FR production exceeds the defense capacity of the organism, a condition known as oxidative stress can occurs and provoke damages to important biomolecules, including DNA, proteins and membrane lipids, compromising cell general functions (Vargas et al., 1991).

Despite of the increasing in the use of medicinal plants in the last decade, the most of them was not sufficiently studied in relation to the quality, safety, efficiency patterns or even in relation to their cytotoxic and mutagenic potential (Bagatini et al., 2007). Currently, the application of M. ilicifolia as medicinal plant is allowed in Brazil, so that their register and commercialization in the phytomedicine don't requires the application of efficiency and safety tests (Brasil, 2011).

However, Maytenus dasyclada have been popularly used as teas without knowledge of their therapeutic properties and their toxic and mutagenic potential. There is no literature that describes the antioxidant activity of the specie in vivo. There is only one manuscript in the literature about chemical characterization and in vitro biological properties of this specie (Schwanz et al., 2013). These work identified the presence of quercetin and kaempherol in ethyl acetate and ethanolic extracts of M. dasyclada, being that both showed antioxidant and antigenotoxic activity in vitro. However, there is no literature describing biological properties of $M$. dasyclada in vivo.

Viewing expands the knowledge about Maytenus genus and their economic and/or medicinal potential, the objective of this study was compare the in vitro antioxidant activity and the in vivo genotoxicity of $M$. dasyclada with the reference species M. aquifolium and M. ilicifolia.

\section{Material and Methods}

The leaves of Maytenus species were collected in the northern Rio Grande do Sul, Brazil. The exsicatas were identified and deposited in the Herbarium Padre Balduino Rambo of the URI University, Erechim, RS, Brazil. The exsicatas were identified by the numbers HPBR 11,512 (M. dasyclada), HPBR 11,508 (M. aquifolium) and HPBR 11,502 (M. ilicifolia) by Dr. Altemir J. Mossi.

The fresh aerial parts of the plant were air-dried at temperature to $30-35^{\circ} \mathrm{C}$ for 5 days, after being broken into small pieces. The extract was obtained by water infusion with $20 \mathrm{~g}$ of the leaves to $100 \mathrm{~mL}$ of distilled water for 15 minutes at $70^{\circ} \mathrm{C}(20 \% \mathrm{w} / \mathrm{v})$. After cooling and filtration, the extract was frozen and concentrated by lyophilization.

The antioxidant activity of Maytenus spp. was evaluated in vitro by the DPPH method. Briefly, the absorbance of free radical 2.2-diphenyl-1-picryl-hydrazil alone (DPPH control) or in the presence of plant extracts $(0.01,0.025$, $0.05,0.075,0.1,0.25$ and $\left.0.5 \mathrm{mg} \cdot \mathrm{mL}^{-1}\right)$ was measured in $515 \mathrm{~nm}$ (Miranda and Fraga, 2006), with ethanol used as solvent and blank. The scavenging activity of extracts upon DPPH radical was calculated as percentage of antioxidant activity (AA\%), using the Equation 1:

$$
\text { AA } \%=100-\left\{\left[\left(\begin{array}{l}
\text { Abs. sample }- \\
\text { Abs. white }
\end{array}\right) \times 100\right] \div \text { Abs. DPPH control }\right\}
$$

The concentration of extract able to scavenge $50 \%$ of $\mathrm{DPPH}$ radical $\left(\mathrm{IC}_{50}\right)$ was calculated through regression analysis.

The content of total polyphenolics (TP) present in the extracts was estimated by a colorimetric assay at $691 \mathrm{~nm}$ in according with Glasl (1983). The percentages of total phenolics were determined in triplicate. Results were expressed as milligrams of galic acid equivalents by grams of extract (mg EAG.g ${ }^{-1}$ ) and were calculated using the Equation 2:

$$
T P(\%)=\frac{15625 \times A b s}{1000 \times M}
$$

where $\mathrm{TP}=$ total polyphenolics $(\%)$; Abs $=$ absorbance of each sample; $M=$ mass $(\mathrm{g})$ of extracts.

The correlation between phenolic content and antioxidant activity in three Maytenus species was performed in Excel.

This study was conducted in accordance with Federal Law N ${ }^{\circ} 11,794$ and was approved by the Research Ethics Committee of URI University (RS, Brazil) upon register numbers 077/TCA/09. Male Wistar rats (Rattus norvegicus Bakenhouff) two months old, weighing $120 \pm 5$ g, were obtained from Laboratory of Animal Experiments of URI University (RS, Brazil). The animals were kept in photoperiod of $12 \mathrm{~h}$ of light and dark, minimal noise $(<20 \mathrm{db})$, ambient temperature $\left(22 \pm 2{ }^{\circ} \mathrm{C}\right)$ and had free access to food and water.

For experimental procedures, the animals were distributed randomly in groups of 6 rats each, and received orally treatments of $75 \mathrm{mg} \cdot \mathrm{kg}^{-1}$. day ${ }^{-1}$ of $\mathrm{NaCl}$ (Salt solution), $330 \mathrm{mg} \cdot \mathrm{kg}^{-1}$. day ${ }^{-1}$ of vitamin C (Vitamin C), $830 \mathrm{mg} \cdot \mathrm{kg}^{-1}$. day ${ }^{-1}$ extract of each species (Extract) and $830 \mathrm{mg} \cdot \mathrm{kg}^{-1}$.day ${ }^{-1}$ of each extract plus $330 \mathrm{mg} \cdot \mathrm{kg}^{-1}$. day ${ }^{-1}$ of vitamin C (Extract plus vitamin C) for 14 days.

After 14 days the rats were sacrificed in $\mathrm{CO}_{2}$ chamber. Total blood was collected by cardiac puncture and transferred to tubes containing heparin. An aliquot was centrifuged to separate the plasma $(5,000 \mathrm{rpm}, 15 \mathrm{~min})$. The samples of blood and plasma were frozen at $-20^{\circ} \mathrm{C}$ and later used to perform, respectively, the comet assay and carbonyl proteins dosage. 
The genotoxicity of Maytenus extracts was evaluated by the alkaline comet assay as described by Singh et al. (1988), with minor modifications. A $5 \mathrm{~mL}$ aliquot of previously collected blood were mixed with $100 \mu \mathrm{L}$ of $0.75 \%$ low-melting point agarose, and immediately spread onto a glass microscope slide pre-coated with $1 \%$ normal melting point agarose. Agarose was allowed to set at $4^{\circ} \mathrm{C}$ for $5 \mathrm{~min}$. To remove cell proteins, slides were incubated with ice-cold lyses solution $(2.5 \mathrm{M} \mathrm{NaCl}$, $10 \mathrm{mM}$ Tris, $100 \mathrm{mM}$ EDTA, $1 \%$ Triton $\mathrm{X}-100$, and $10 \%$ DMSO, $\mathrm{pH} 10.0$ ) at $4{ }^{\circ} \mathrm{C}$ for at least $1 \mathrm{~h}$. To promote DNA unwinding and the exposure of alkali-labile sites, slides were placed on a horizontal electrophoresis unit, covered with fresh buffer (300mM NaOH, 1mM EDTA, pH 13.0) for $20 \mathrm{~min}$ at $4^{\circ} \mathrm{C}$. Electrophoresis was performed in alkaline conditions $(\mathrm{pH} \sim 13$ ) for $15 \mathrm{~min}$ at $25 \mathrm{~V}$ and $300 \mathrm{~mA}$. After electrophoresis, slides were neutralized (0.4M Tris, $\mathrm{pH} 7.5)$, washed in bi-distilled water, stained with silver solution ( $0.1 \%$ ammonium nitrate; $0.1 \%$ de silver nitrate; $0.25 \%$ tungstosilicic acid; $0.15 \%$ formaldehyde), dried overnight and analyzed by optical microscopy. In order to prevent additional DNA damage, the slides preparation was made in a dark room.

For each animal were prepared two independently slides, being evaluated 100 random cells in each one. Cells were visually scored according to tail length into five classes, from 0 (undamaged, without a tail) to 4 (maximum damage, comets with no heads). A damage index (DI) was assigned to each comet according to its class. The damage index is based on the length of migration and on the amount of DNA in the tail, and it is considered a sensitive DNA measurement. Damage index, can range from 0 (completely undamaged 100 cells $\times 0$ ) to 400 (with maximum damage 100 cells $\times 4$ ).

Evaluation of oxidative damage in plasmatic proteins was based on detection of carbonyl groups by reaction with 2,4-dinitrophenylhydrazine (DNPH). Previously collected plasma samples were mixed with acetic glacial acid $(0.2 \mathrm{~mL})$, incubated on the ice $(5 \mathrm{~min})$, centrifuged $(10,000 \mathrm{rpm}, 5 \mathrm{~min})$ and the supernatant was discarded. The remained precipitate received $1 \mathrm{~mL}$ of DNPH $(10 \mathrm{mM})$ and was incubated at $37^{\circ} \mathrm{C}$ for $60 \mathrm{~min}$. A blank was made using $\mathrm{HCl}(2 \mathrm{M})$ instead DNPH. Following the samples was mixed in vortex (30s), centrifuged (10,000rpm, $5 \mathrm{~min})$ and precipitated proteins dissolved in $6 \mathrm{M}$ guanidine. The latter procedure was repeated three times; in the last, the supernatant phase was collected and subjected to carbonyl content determination by measure of absorbance at $370 \mathrm{~nm}$ (Levine et al., 1990) and total protein quantification by Bradford method (Bradford, 1976).

The results were analyzed statistically using one-way ANOVA plus Tukey's post-test, with $p$ values $<0.05$ accepted as significant.

\section{Results and Discussion}

In these work the in vitro antioxidant activity and the in vivo genotoxicity of Maytenus dasyclada was compared to the reference species $M$. aquifolium and M. ilicifolia.
As elucidated by DPPH method, M. dasyclada as well the two other Maytenus spp. investigated, showed in vitro antioxidant activity (Table 1 ), but $M$. ilicifolia was clearly more efficient as radical scavenger since its $\mathrm{IC}_{50}$ is dozens of times smaller. The DPPH result obtained to M. ilicifolia is similar to previously published data (Pessuto et al., 2009). In these sense, is possible conclude that M. dasyclada have antioxidant capacity comparable to the M.aquifolium which, in its turn, acts as scavenger of several oxidants, including $\mathrm{O}_{2}^{--}$, NO and HCOl (Vellosa et al., 2007).

Total phenols content was also similar in M. dasyclada and $M$. aquifolium, both species showing values that are approximately half of $M$. ilicifolia (Table 1). Using another methodology, Pereira et al. (2005) has demonstrated that the yields of phenolic compounds in M. ilicifolia can indeed be until three fold higher than in M. aquifolium (14 to $20 \%$ and 4.23 to $7.53 \%$, respectively). No previous data were found in the literature about total polyphenols content in $M$. dasyclada.

Is interesting to note that in the three species, DPPH $\mathrm{IC}_{50}$ is inversely correlated with phenolic results and this correlation shown a good linear regression (Pearson correlation of - 0.932 ) (Figure 1), suggesting the importance of phenolic compounds to antioxidant proprieties of the genus. A similar correlation had previously been demonstrated to ethanolic and aqueous extracts of M. ilicifolia using DPPH and phosphomolybdenum assay; being that the antioxidant potential of ethanolic extract was better than aqueous extract and was also proportionally increased by the presence of hydroxylated phenolic groups in the fraction (Pessuto et al., 2009).

Table 1. Antioxidant activity and phenolic content of Maytenus spp. aqueous extracts.

\begin{tabular}{lcc}
\hline \multicolumn{1}{c}{ Specie } & $\begin{array}{c}\text { DPPH IC } \\
\text { (mg.mL }^{-1} \text { ) }\end{array}$ & $\begin{array}{c}\text { Phenolic content } \\
\left(\mathbf{m g ~ E A G . g ^ { - 1 }}\right)\end{array}$ \\
\hline M. dasyclada & $0.990 \pm 0.033$ & $22 \pm 1.03$ \\
M. aquifolium & $0.584 \pm 0.021$ & $24 \pm 0.96$ \\
M. ilicifolia & $0.030 \pm 0.001$ & $50 \pm 1.42$ \\
\hline
\end{tabular}

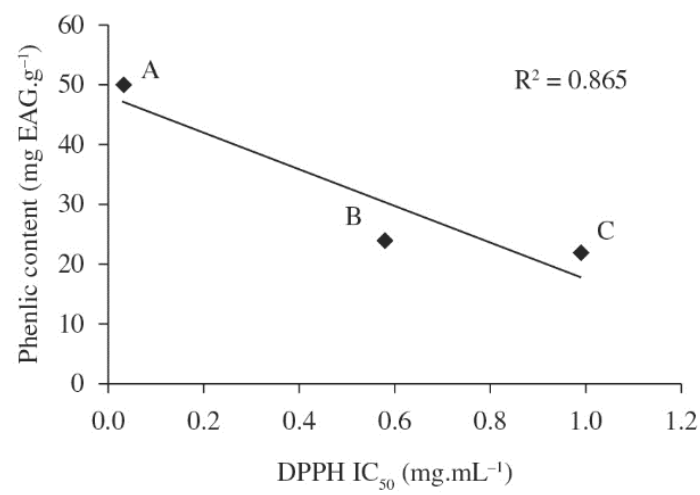

Figure 1. Correlation between phenolic content and antioxidant activity in three Maytenus spp. (A) M. ilicifolia, (B) M. aquifolium and (C) M. dasyclada. 
Antioxidant-rich fractions (e.g. polyphenols) from plant extracts have been used in experimental models to prove their inhibitory effect on induced ulceration (Vilegas et al., 1999). The protective effect of rutin, a widespread flavonol glycoside, against ethanol induced gastric lesions as well as the inhibition of gastric $\mathrm{H}^{+}$, $\mathrm{K}^{+}$- ATPase by catechins have already been assessed (La Casa et al., 2000). The presence of polyphenols and the antioxidant activity on Maytenus spp. can contribute for the efficiency of its infusion as an antiulcer agent and legitimate its medicinal use (Corsino et al., 2003). Besides the best characterized M. ilicifolia, other species of the same genus can became, with greater or lesser intensity, pharmacological alternatives.

To ensure their secure use, is important know the biological effects of the plants in vivo. In this work the genotoxicity of the Maytenus extracts and their ability to oxidize proteins was investigated by the comet assay and carbonyl proteins measure, respectively. The alkaline comet assay is able to detect DNA strand breaks produced by ROS or other toxic substances; it is a sensible and low cost test widely used in the analysis of genotoxicity (Collins et al., 2008). Considering that the maximum DNA damage index (DI) that can be achieved in the comet assay is 400 , the results showed that the three Maytenus spp. have induced a low and similar level of genotoxicity, which was partially recovered by a co-treatment with vitamin $\mathrm{C}$ (Figure 2). In relation to the carbonyl content, $M$. dasyclada and M. aquifolium extracts have also a similar effect, promoting the in vivo protein oxidation (Figure 3). Again, this effect could be reverted by combination with vitamin $\mathrm{C}$.

Although the extracts studied had in vitro antioxidant activity, the reduction of DNA damages by vitamin $\mathrm{C}$ is an indicative that their slight genotoxic effect in vivo can be mediated by an oxidative mechanism. This observation is in agreement with the pro-oxidant action upon proteins (Figures 2 and 3). M. ilicifolia does not cause significant change upon carbonyl content, which can be related with its high content of phenolic compounds comparative to the two other analyzed species (Table 1). The in vivo antioxidant properties of M. ilicifolia were previously demonstrated (Melo et al., 2001) and seems be important to the protection of gastric lesions in rats (Baggio et al., 2007).

Despite the use of Maytenus ilicifolia as medicinal plant, there are few works that have investigated their genotoxic effects. Camparoto et al. (2002) showed that infusions of M. ilicifolia no produce alterations on the cell cycle and chromosomes structure of onion root and bone-marrow cells, while Vargas et al. (1991) demonstrated that the plant is not mutagenic in the AMES test using Salmonella typhimurium as biological model. The clinical toxicology of the M. ilicifolia has also been investigated in humans and the plant does not altered biochemical e hematologic parameters in the subjects (Tabach et al., 2002).

Particularly, the comet assay was not previously employed with all Maytenus spp. target of the present study in vivo, only in vitro experiments (Schwanzet al., 2013). Although the three species have presented a slight increase

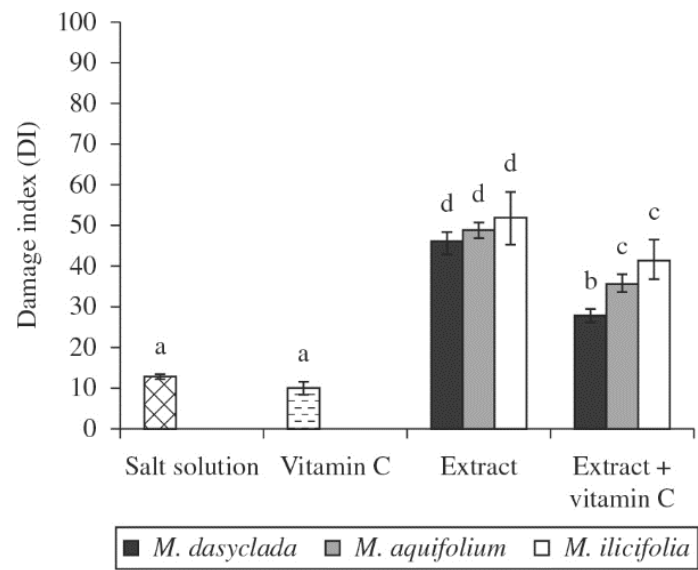

Figure 2. Genotoxicity of the three Maytenus species in rats leukocytes. Animals were treated with salt solution $\left(75 \mathrm{mg} \cdot \mathrm{kg}^{-1} \cdot \mathrm{day}^{-1}\right)$, vitamin C $\left(330 \mathrm{mg} \cdot \mathrm{kg}^{-1} \cdot \mathrm{day}^{-1}\right)$, extract $\left(830 \mathrm{mg} \cdot \mathrm{kg}^{-1} \cdot\right.$ day $\left.^{-1}\right)$ or extract $\left(830 \mathrm{mg} \cdot \mathrm{kg}^{-1} \cdot \mathrm{day}^{-1}\right)$ plus vitamin C (330 mg. $\left.\mathrm{kg}^{-1} \cdot \mathrm{day}^{-1}\right)$ for 14 days. Statistically significant differences between the treatments are indicated by different letters using one-way ANOVA plus Tukey's post test.

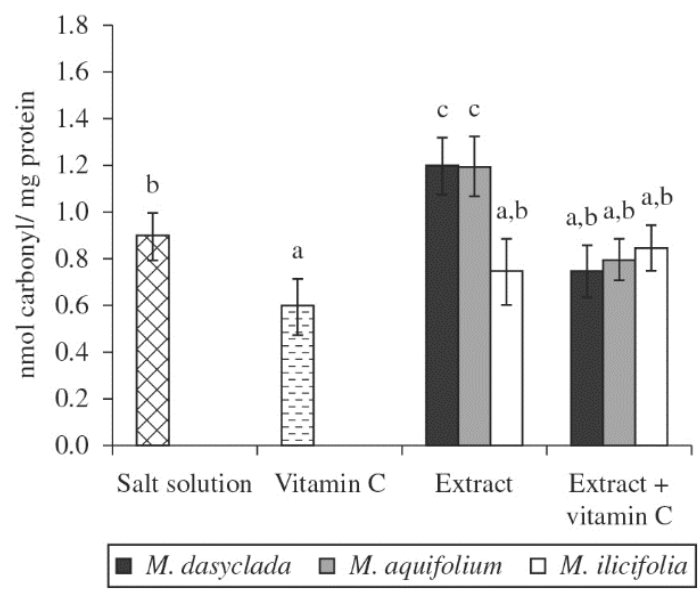

Figure 3. Oxidative damage produced by three Maytenus species in plasmatic proteins of rats. Animals were treated with salt solution $\left(75 \mathrm{mg} \cdot \mathrm{kg}^{-1} \cdot \mathrm{day}^{-1}\right)$, vitamin C $\left(330 \mathrm{mg} \cdot \mathrm{kg}^{-1} \cdot \mathrm{day}^{-1}\right)$, extract $\left(830 \mathrm{mg} \cdot \mathrm{kg}^{-1} \cdot \mathrm{day}^{-1}\right)$ or extract (830 mg.kg ${ }^{-1}$.day $\left.{ }^{-1}\right)$ plus vitamin C (330 mg.kg ${ }^{-1}$.day $\left.{ }^{-1}\right)$ for 14 days. Statistically significant differences between the treatments are indicated by different letters using one-way ANOVA plus Tukey's post test.

in DI, the obtained values are comparable to that seemed in other medicinal plants. Treatment of rats with Calendula officinalis during the same time employed in this study results in similar comet levels (DI 34-72 for $C$. officinalis versus 46-52 for Maytenus spp.); and even so C. officinalis have an antigenotoxic effect that repair the DNA damage caused by methyl methanesulfonate (Leffa et al., 2012). Extracts of Baccharis trimera, showing DI value in the same range, have also protective action against DNA 
breaks induced by hydrogen peroxide (Rodrigues et al., 2009). Schwanz et al. (2013) evaluating the in vitro antioxidative effects of different extracts of Maytenus dasyclada, observed reduction in the DI compared to the control, with 100 and $10 \mu \mathrm{g} / \mathrm{mL}$, regard less of the fraction of the extract (ethyl-acetate or ethanolic).

\section{Conclusions}

The aforementioned data permit to conclude that therapeutic application of M. ilicifolia is secure in male Wistar rats. However, some cautions relative to dosage and/ or time of use as well take into account some particularities of the subjects are necessary. In this work we demonstrated that $M$. dasyclada as antioxidant activity in vitro, and that its genotoxic and pro-oxidant effects in vivo are comparable to the M. ilicifolia and M. aquifolium.

\section{Acknowledgements}

The authors thanks to CNPq, CAPES, FAPERGS and SCIT-RS to financial support.

\section{References}

BAGATINI, MD., SILVA, ACF. and TEDESCO, SB., 2007. The use of Allium cepa test as a bioindicator of genotoxicity of medicinal plants infusions.Brazilian Journal of Pharmacognosy, vol. 17 , p. 444-447.

BAGGIO, CH., FREITAS, CS., OTOFUJI, GM., CIPRIANI, TR., SOUZA, LM., SASSAKI, GL., IACOMINI, M., MARQUES, MC. and MESIA-VELA, S., 2007. Flavonoid-rich fraction of Maytenus ilicifolia Mart. ex. Reiss protects the gastric mucosa of rodents through inhibition of both $\mathrm{H}+, \mathrm{K}+-$ ATPase activity and formation of nitric oxide.Journal of Ethnopharmacology, vol. 113, no. 3, p. 433-440. http://dx.doi.org/10.1016/j.jep.2007.06.015. PMid: 17706386

BRADFORD, MM., 1976. A rapid and sensitive method for the quantitation of microgram quantities of protein utilizing the principle of protein-dye binding.Analytical Biochemistry, vol. 72, no. 1-2, p. 248-254. http://dx.doi.org/10.1016/00032697(76)90527-3. PMid:942051

Brasil. Agência Nacional de Vigilância Sanitária - ANVISA,2011. Formulário de Fitoterápicos da Farmacopeia Brasileira. Brasília: ANVISA.

CAMPAROTO, ML., TEIXEIRA, RO., MANTOVANI, MS. and VICENTINI, VEP., 2002. Effects of Maytenus ilicifolia Mart. and Bauhinia candicans Benth infusions on onion root-tip and rat bone-marrow cells.Genetics and Molecular Biology, vol. 25, no. 1, p. 85-89. http://dx.doi.org/10.1590/S1415-47572002000100016.

COLLINS, AR., OSCOZ, AA., BRUNBORG, G., GAIVÃO, I., GIOVANNELLI, L., KRUSZEWSKI, M., SMITH, CC. and STETINA, R., 2008. The comet assay: topical issues.Mutagenesis, vol. 23, no. 3, p. 143-151. http://dx.doi.org/10.1093/mutage/ gem051.PMid:18283046

CORSINO, J., SILVA, DHS., ZANONI, MVB., BOLZANI, VS., FRANÇA, SC., PEREIRA, AM. and FURLAN, M., 2003. Antioxidant flavan-3-ols and flavonol glycosides from Maytenus
aquifolium.Phytotherapy research : PTR, vol. 17, no. 8, p. 913916. http://dx.doi.org/10.1002/ptr.1249. PMid:13680823

GALVÃO, EL., SILVA, DCF., SILVA, JO., MOREIRA, AVB. and SOUSA, EMBD., 2008. Evaluation of the antioxidant potential and sub-critical extraction of linseed oil.Ciência e Tecnologia de Alimentos, vol. 28, no. 3, p. 551-557.

GLASL, H., 1983. ZurPhotometrie in der drogenstandardisierung -3. Gehaltsbestimmung von gerbstoffdrogen.Deutsche ApothekerZeitung, vol. 123, p. 1979-1987.

HALLIWELL, B. and GUTTERIDGE, JMC., 2007. Free Radicals in biology and medicine. 4th ed. New York: Oxford University Press Inc.

LA CASA, C., VILLEGAS, I., ALARCÓN DE LA LASTRA, C., MOTILVA, V. and MARTÍN CALERO, MJ., 2000. Evidence for protective and antioxidant properties of rutin, a natural flavone, against ethanol induced gastric lesions.Journal of Ethnopharmacology, vol. 71, no. 1-2, p. 45-53. http://dx.doi. org/10.1016/S0378-8741(99)00174-9. PMid:10904145

LEFFA, DD., ROSA, R., MUNHOZ, BP., MELLO, AAM., MANDELLI, FD., AMARAL, PA., ROSSATTO, AE. and ANDRADE, VM., 2012. Genotoxic and antigenotoxic properties of Calendula officinalis extracts in mice treated with methyl methanesulfonate.Advances in Life Sciences, vol. 2, no. 2, p. 21-28. http://dx.doi.org/10.5923/j.als.20120202.05.

LEVINE, RL., GARLAND, D., OLIVER, CN., AMICI, A., CLIMENT, I., LENZ, AG., AHN, BW., SHALTIEL, S. and STADTMAN, ER., 1990. Determination of carbonyl content in oxidatively modified proteins.Methods in Enzymology, vol. 186, p. 464-478. http://dx.doi.org/10.1016/0076-6879(90)86141-H. PMid: 1978225

MARIOT, MP. and BARBIERI, RL., 2007. Metabólitos secundários e propriedades medicinais da espinheira-santa (Maytenus ilicifolia Mart. ex Reiss. e Maytenus aquifolium Mart.).Revista Brasileira de Plantas Medicinais, vol. 9, no. 3, p. 89-99.

MELO, SF., SOARES, SF., COSTA, RF., SILVA, CR., OLIVEIRA, MB., BEZERRA, RJ., CALDEIRA-DE-ARAÚJO, A. and BERNARDO-FILHO, M., 2001. Effect of the Cymbopogon citratus, Maytenus ilicifolia and Baccharis genistelloides extracts against the stannous chloride oxidative damage in Escherichia coli.Mutation Research, vol. 496, no. 1-2, p. 33-38. http://dx.doi. org/10.1016/S1383-5718(01)00216-9.PMid:11551478

MIRANDA, ALP. and FRAGA, CAM., 2006. Atividade sequestradora de radical livre determinação do potencial antioxidante de substâncias bioativas. In MONGE, A. and GANELLIN, CR. (Eds.). Practical Studies for Medicinal Chemistry. IUPAC. p. 1-14.Available from: $<$ http://www.iupac.org/fileadmin/user_upload/publications/cd/ Medicinal-Chemistry/Practica-I-5.pdf>. Access in: 10 Mar. 2015.

MOSSI, AJ., MAZUTTI, M., PAROUL, N., CORAZZA, ML., DARIVA, C., CANSIAN, RL. and OLIVEIRA, JV., 2009. Chemical variation of tannins and triterpenes in Brazilian populations of Maytenus ilicifolia Mart. Ex Reiss.Brazilian Journal of Biology, vol. 69, no. 2, p. 339-345. http://dx.doi.org/10.1590/S151969842009000200015 .

PEREIRA, AMS., JANUÁRIO, AH., QUEIROZ, MEE., BIONDO, R. and FRANÇA, SC., 2005. Evaluation of Maytenus aquifolium Mart. and Maytenus ilicifolia Mart. chemotypes for tannins, total phenols and triterpenes.Revista Brasileira de Plantas Medicinais, vol. 8 , no. 1, p. 13-17. 
PESSUTO, MB., COSTA, IC., SOUZA, AB., NICOLI, FM., MELLO, JCP., PETEREIT, F. and LUFTMANN, H., 2009. Antioxidant activity of extracts and condensed tannins from leaves of Maytenus ilicifolia Mart. ex Reiss.Quimica Nova, vol. 32, no. 2, p. 412-416. http://dx.doi.org/10.1590/S0100-40422009000200027.

RODRIGUES, CR., DIAS, JH., DE MELLO, RN., RICHTER, MF., PICADA, JN. and FERRAZ, AB., 2009. Genotoxic and antigenotoxic properties of Baccharis trimera in mice.Journal of Ethnopharmacology, vol. 125, no. 1, p. 97-101. http://dx.doi. org/10.1016/j.jep.2009.06.006. PMid:19539021

SANTOS-OLIVEIRA, R., COULAUD-CUNHA, S. and COLAÇO, W., 2009. Review of Maytenus ilicifolia Mart. Ex Reissek, Celastraceae. Contribution to the studies of pharmacological properties.Brazilian Journal of Pharmacognosy, vol. 19, no. 2b, p. 650-659.

SCHWANZ, M., DRESCH, RR., MANFREDINI, V. and HENRIQUES, AT., 2013. Antioxidative effects of Maytenus dasyclada Mart. (Celastraceae).International Journal of Pharma and Bio Sciences, vol. 4, no. 3, p. 957-969.

SINGH, NP., MCCOY, MT., TICE, RR. and SCHNEIDER, EL., 1988. A simple technique for quantitation of low levels of DNA damage in individual cells. Experimental Cell Research, vol. 175, no. 1, p. 184-191. http://dx.doi.org/10.1016/0014-4827(88)902650. PMid:3345800

SOARES, M., WELTER, L., GONZAGA, L., LIMA, A., MACINIFILHO, J. and FETT, R., 2008. Evaluation of antioxidant activity and identification of phenolic acids present in the pomace of
Gala variety apples.Ciência e Tecnologia deAlimentos, vol. 28, no. 3, p. 727-732.

SOUZA-FORMIGONI, ML., OLIVEIRA, MG., MONTEIRO, MG., SILVEIRA-FILHO, NG., BRAZ, S. and CARLINI, EA., 1991. Antiulcerogenic effects of two Maytenus species in laboratory animals.Journal of Ethnopharmacology, vol. 34, no. 1, p. 21-27. http://dx.doi.org/10.1016/0378-8741(91)90185-G. PMid:1753784

TABACH, R., CARLINI, E. and MOURA, YG., 2002. Um novo extrato de Maytenus ilicifolia Mart. ex Reiss. (Toxicologia clínica - Fase I) Avaliação em seres humanos.Revista Racine, vol. 71 , p. 38-43.

VARGAS, VMF., GUIDOBONO, RR. and HENRIQUES, JAP., 1991. Genotoxicity of plant extracts.Memorias do Instituto Oswaldo Cruz, vol. 86, no. 2, supplement 2, p. 67-70. http:// dx.doi.org/10.1590/S0074-02761991000600017. PMid:1842016

VELLOSA, JCR., BARBOSA, VF., KHALIL, NM., SANTOS, VAFFM., FURLAN, M., BRUNETTI, IL. and OLIVEIRA, OMMF., 2007. Profile of Maytenus aquifolium action over free radicals and reactive oxygen species.Brazilian Journal of Pharmaceutical Sciences, vol. 43, no. 3, p. 447-453.

VILEGAS, W., SANOMMIYA, M., RASTRELLI, L. and PIZZA, C., 1999. Isolation and structure elucidation of two new flavonoid glycosides from the infusion of maytenus aquifolium leaves. Evaluation of the antiulcer activity of the infusion.Journal of Agricultural and Food Chemistry, vol. 47, no. 2, p. 403-406. http://dx.doi.org/10.1021/jf980114i. PMid:10563907 